\title{
CHEESE WHEY AS A NATURAL SOURCE OF PEROXIDASE TO AMELIORATE THE NEGATIVE EFFECTS OF PHENOLIC COMPOUNDS OF FEED INGREDIENTS AND THE GOSSYPOL OF COTTONSEEDS IN RABBITS DIETS. \\ Mehrez, A. Z.*;M. A. El-Harairy*; W. A. Khalil* ; M. A. Shetefa** and M. M. Salama**. \\ *Anim. Prod. Dept., Fac. of Agric., Mansoura University, Egypt. \\ ${ }^{* *}$ Anim. Prod. Res. Insit., Agric. Res. Cent., Ministry of Agric. Egypt.
}

\begin{abstract}
This study was conducted to investigate the influence of 3 levels of cheese whey as a natural source of peroxidase to overcome the negative effects of polyphenolic compounds naturally found in feed ingredients of rabbit feed. Thirty New Zealand growing rabbits were used. The rabbits were divided according to body weight into 5 similar experimental groups. They were assigned at random to receive the 5 experimental diets. The control ration was a commercial diet. Un-decorticated cotton seed cake partially replaced soybean meal protein in the second diet. The other 3 experimental diets were the same as diet 2 but supplemented with 1, 2, and $3 \%$. of cheese whey, respectively. The experiment lasted for 72 days to study the effects on nutrients digestibility and feeding values, growth performance, and economical efficiency.

Results showed that rabbits fed diet containing $3 \%$ whey recorded significant increase in digestibility coefficients of DM, OM, CP, CF, EE and NFE compared to the other ratios while diets which contained 2 or $3 \%$ whey had higher digestibility of NDF, ADF, hemi- cellulose, cellulose and lignin. The nutritive value as TDN, DE and ME significantly $(P<0.01)$ increased with 2 or $3 \%$ whey. Final body weights were 2545 , $2248.33,2466.67,2470.50$ and $2456.67 \mathrm{~g}$. for animals fed the control, 0, 1, 2 and $3 \%$ whey, respectively. Corresponding averages of daily gains were $26.02,21.78,24.84$, 24.85 and $24.63 \mathrm{~g}$. These results revealed significant $(P<0.05)$ improvement in growth performance in response to whey supplementation. In addition, economical efficiency and relative economic efficiency were the best for the group fed $1 \%$ whey (163.41 and $119.27 \%$ ) followed by the other groups. It was concluded that cheese whey could be used as a natural source of peroxidase to ameliorate the negative effects of phenolic compounds naturally found in feed ingredients and the gossypol of cotton seeds.

Keywords: Rabbits, cotton seed meal, cheese whey, peroxidase, nutrient digestibility, growth performance, economical efficiency.
\end{abstract}

\section{INTRODUCTION}

Rabbits and poultry have fast reproductive and growth rates, and are excellent species in converting feed into body weight. Both are known to yield high quality protein meat with low fat. Rabbits also have a small body size but can be raised on relatively small amounts of non-conventional feedstuffs. They can be raised on grain-free diets, mainly on forages and other type of agricultural by-products. The specific advantages of rabbits have been reviewed by Cheeke, (1987). Some of these advantages make rabbits a suitable livestock species for meat production in the developing nations. The anti-nutritive factors (ANFs) may be defined as those substances generated in natural feedstuffs by the normal metabolism of species and by different 
mechanisms e.g inactivation of some nutrients, interference with the digestive process or metabolic utilization of feed which exert effects contrary to optimum nutrition. Being an ANF is not an intrinsic characteristic of a compound but depends upon the digestive process of the ingesting animal.

Soybean meal commonly used in animal diets is becoming very expensive. Un-decorticated cottonseed meal is cheaper but it contains appreciable amounts of gossypol and some feed ingredients contain polyphenolic compounds which are considered anti-nutritional factors.

Whey is the valuable co-product resulting after the production of cheese, curd cheese or casein from milk. The type of whey produced depends on the method of precipitation that is employed to separate the casein. Whey products have been successfully used in feed for young animals (e.g. in milk replacer for calves, lambs and goat kids and also in diets for weaned pigs). Moreover, whey products are increasingly being used in animal feed for both breeding and fattening purposes (EWPA, 2006). It is rich in peroxidase. Peroxidases have conquered a prominent position in biotechnology and associated research areas (enzymology, biochemistry, medicine, genetics, physiology, histo- and cytochemistry). They are one of the most extensively studied groups of enzymes and the literature is rich in research papers dating back from the 19th century. Nasrabadi and Asadpour (2008) determined the LP activity of buffalo milk, it was found to be $16.84 \mathrm{U} /$ $\mathrm{mL}$. also, reported buffalo milk LP is more susceptible to increases of temperature above $71^{\circ} \mathrm{C}$ than lower temperature. Lacto-peroxidase is one of the most stabilized enzymes in milk (Shakeel- ur- Rehman and Farkye, 2002). The importance of peroxidases is emphasised by their wide distribution among living organisms and by their multiple physiological roles. They have been divided into three super families according to their source and mode of action: plant peroxidases, animal peroxidases and catalases (Azevedo. et al., 2003).

\section{MATERIALS AND METHODES}

Animals:

Thirty growing male New Zealand White (NZW) rabbits at 5 weeks of age were used in this study. The rabbits were divided according to body weight into 5 similar groups ( 6 in each). The 5 groups were assigned at random to 5 experimental dietary treatments. The initial live body weight were $0.641,0.694,0.690,0.700$ and $0.698 \mathrm{~kg}$, respectively. The experimental period lasted 72 days. Rabbits were individually weighed every 24 days in the morning before feeding.

Housing and management:

Male rabbits used in this study were individually housed in double flat galvanized wire cages $(40 \times 50 \times 60 \mathrm{~cm})$. Each cage had feeder and stainless nipple for drinking water. The batteries were arranged in rows in a windowed house and feeds and water were available all time, through the provision of feed twice a day. Rabbits of all groups were individually kept under the same managerial conditions. 


\section{Experimental diets:}

Five iso- nitrogenous and iso- calories total mixed rations (TMR) were formulated to cover the nutrient requirements for breeding and mature rabbits according to NRC (1994), as presented in Table 1.The control ration was a commercial diet. Un-decorticated cotton seed cake replaced $20 \%$ of soybean meal protein in the second diet. The other 3 experimental diets were supplemented with 1,2 , and $3 \%$. of cheese whey, respectively. All experimental diets were in pelleted form.

Table 1: Formulation of the experimental diets (\%).

\begin{tabular}{|l|c|c|c|c|c|}
\hline Ingredient. & $\begin{array}{c}\mathbf{R} 1 \\
\text { Control }\end{array}$ & $\begin{array}{c}\text { R2 } \\
\text { 0\% Whey }\end{array}$ & $\begin{array}{c}\text { R3 } \\
\text { 1\% Whey }\end{array}$ & $\begin{array}{c}\text { R4 } \\
\mathbf{2 \%} \text { Whey }\end{array}$ & $\begin{array}{c}\text { R5 } \\
\text { 3\% Whey }\end{array}$ \\
\hline Barley grain & 22 & 22 & 22 & 22 & 22 \\
\hline Wheat bran & 26 & 26 & 26 & 26 & 26 \\
\hline Berseem hay 3 ${ }^{\text {rd }}$ cut & 30 & 30 & 30 & 30 & 30 \\
\hline Soybean meal & 17 & 10 & 10 & 10 & 10 \\
\hline UD CSM & 0 & 6.5 & 6.5 & 6.5 & 6.5 \\
\hline Molasses & 3 & 3.5 & 3.5 & 3.5 & 3.5 \\
\hline Salt & 0.5 & 0.5 & 0.5 & 0.5 & 0.5 \\
\hline Limestone & 1 & 1 & 1 & 1 & 1 \\
\hline Premix & 0.5 & 0.5 & 0.5 & 0.5 & 0.5 \\
\hline Total & 100 & 100 & 100 & 100 & 100 \\
\hline Cheese whey (\%) & - & - & 1 & 2 & 3 \\
\hline
\end{tabular}

Premix*: One kilogram of premix contain:vit. A 12000000 IU, vit. D3 220000 IU, vit. E 1000 mg, vit. $K_{3} 2000 \mathrm{mg}$, vit. $B_{1} 1000 \mathrm{mg}$, vit. $B_{2} 4000$, vit. $B_{6} 100 \mathrm{mg}$, vit. $B_{12} 10 \mathrm{mg}$, pantothenic acid $3.33 \mathrm{~g}$, biotin $33 \mathrm{mg}$, folic acid $0.83 \mathrm{~g}$, cholin chloride $200 \mathrm{~g}, \mathrm{Zn} 11.79 \mathrm{~g}$, Mn5 g, Fe 12.5 $\mathrm{g}$, Cu $0.5 \mathrm{~g}, \mathrm{I} 33.3 \mathrm{mg}$, Se $16.6 \mathrm{mg}$ and $\mathrm{Mg} 66.7 \mathrm{~g}$.

\section{Digestibility trails:}

Five digestibility trails were carried out using three NZW rabbits from each group. Rabbits were fed in such away to cover their requirements (NCR, 1994). Rabbits were weighed at the beginning and the end of the collection period to make sure that their weights were maintained. The preliminary period was 3 days, followed by 4 days as a collection period. Quantitative collection of feces started 24 hours post-offering the daily feed, the feces of each rabbit was collected every day in the morning shaded hair were eliminated. The feces were dried at $60^{\circ} \mathrm{C}$ for 48 hours. At the end of collection, all collected feces for each rabbit was weighed, pooled and stored at $(2-5)^{\circ} \mathrm{C}$ for chemical analysis purpose. Proximate analysis were carried out according to ( A.O.A.C, 1990), crude protein (CP) by Kjeldahl, while nitrogen free extract (NFE) was calculated by difference. Fiber fractions (NDF, ADF and ADL) were determined as described by (Goering and Van Soest, 1970). Hemicelluloses and cellulose were calculated by difference.

\section{Statistical Analysis:}

Data were subjected to analysis of variance according to Snedecor and Cochran, (1982) using General Linear Model program of SAS (2001). Significant difference among treatments were identified at $5 \%$ level by Duncan (1955) multiple range tests. 


\section{RESULTS AND DISCUSSION}

\section{Chemical analysis of the experimental diets:}

Chemical analysis of Un-decorticated cottonseed meal (UCSM) and the five experimental diets are presented in table 2 . The proximate analysis of UCSM recorded 92.00, 92.14, 24, 23, 6.20, 38.94 and 7.86\% for DM, OM, CP, CF, EE, NFE and ash, respectively. Azhdari et al., (2012) reported that chemical analyses of CSM was $91.7 \%$ DM, $43.7 \% \mathrm{CP}, 13 \% \mathrm{CF}, 1.6 \% \mathrm{EE}$ and $6.6 \%$ ash. Dadgar et al., (2010) reported that chemical analyses of CSM was as follows: $91.92 \% \mathrm{DM}, 36.9 \% \mathrm{CP}, 10.6 \% \mathrm{CF}, 4.72 \%$ ash, and 2250 $\mathrm{Kcal} / \mathrm{Kg}$ energy on DM basis. Ojewola et al., (2006) reported that chemical analysis of CSM was $89.38 \%$ DM, 39.86\% CP, $17.38 \% \mathrm{CF}, 6.57 \% \mathrm{EE}$ and $6.79 \%$ ash., Also, Erturk, et al., (2004) showed that chemical analysis of extracted CSM was $92.79 \%$ DM, $87.9 \%$ OM, $30.56 \%$ CP, $17.1 \%$ CF, $34.44 \%$ NFE, $5.8 \% \mathrm{EE}$, and $4.89 \%$ ash

Table 2:Chemical analysis of different experimental diets.

\begin{tabular}{|c|c|c|c|c|c|c|}
\hline \multirow[b]{2}{*}{ Ingredient } & \multirow[b]{2}{*}{ UCSM } & \multicolumn{5}{|c|}{ Experimental rations } \\
\hline & & $\begin{array}{c}\mathrm{R} 1 \\
\text { Control }\end{array}$ & $\begin{array}{c}\text { R2 } \\
0 \% \\
\text { Whey }\end{array}$ & $\begin{array}{c}\text { R3 } \\
1 \% \\
\text { Whey }\end{array}$ & $\begin{array}{c}\text { R4 } \\
2 \% \\
\text { Whey }\end{array}$ & $\begin{array}{c}\text { R5 } \\
\mathbf{3} \% \\
\text { Whey }\end{array}$ \\
\hline (DM) & 92.00 & 88.62 & 88.76 & 89.69 & 90.62 & 91.55 \\
\hline \multicolumn{7}{|c|}{ Chemical analysis ( $\%$ as DM basis): } \\
\hline (OM) & 92.14 & 92.14 & 92.12 & 92.03 & 91.94 & 91.84 \\
\hline (CP) & 24 & 16.85 & 16.30 & 16.43 & 16.56 & 16.70 \\
\hline (CF) & 23 & 13.92 & 14.43 & 14.43 & 14.43 & 14.44 \\
\hline (EE) & 6.20 & 2.43 & 2.64 & 2.65 & 2.65 & 2.66 \\
\hline (NFE) & 38.94 & 58.94 & 58.75 & 58.52 & 58.3 & 58.04 \\
\hline Ash & 7.86 & 7.86 & 7.88 & 7.97 & 8.06 & 8.16 \\
\hline \multicolumn{7}{|c|}{ Fiber fractions: } \\
\hline NDF & 40 & 39.14 & 39.61 & 39.5 & 39.38 & 39.38 \\
\hline ADF & 29 & 22.13 & 22.59 & 22.59 & 22.59 & 22.60 \\
\hline $\mathrm{ADL}$ & 11 & 7 & 7 & 7 & 7 & 7 \\
\hline Hemi-cellulose & 21 & 17.11 & 17.02 & 16.91 & 16.79 & 16.68 \\
\hline Cellulose & 18 & 15.13 & 15.59 & 15.59 & 15.59 & 15.60 \\
\hline
\end{tabular}

Digestibility coefficients and nutritive values of the experimental diets :

The nutrients digestibility coefficient and nutritive values of the experimental rations are presented in Table 3 . Results showed that animal fed diet 2 (0\% whey) containing 6.5\% UCSM replacing SBM recorded lowered digestibility of all nutrients compared with this fed diet 1 ( control diet). At the same time, animal fed diet 2 ( $0 \%$ whey) recorded lowered digestibility Fiber fractions (NDF, ADF, ADL, hemi-cellulose and cellulose) and Nutritive values (TDN, DCP, DE and ME) compared with this fed the diet 1 (control diet). The recorded digestibility coefficients of CP were 81.15, $78.27,78.01,80.89$ and $82.24 \%$ for rations control, D2 - D5, respectively, it is clearest that diet 2 decreased compared with control diet but ration 5 (3\% whey) recorded highest significant $(P<0.01)$ value for $C P$. The same higher 
significant $(P<0.01)$ value was observed for CF, EE and NFE digestibility for ration 5 (3\% whey). These results are in agreement with Abd El- Hadi, (2011) who reported that the digestion coefficients of DM, OM,CP, CF, EE and ash were improved $(P<0.05)$ with calves fed diet supplemented with 2 or $3 \%$ whey compared with animals fed the control diet ( $0 \%$ whey). The improvement in digestibility may be attributed to the positive effect of lactoperoxidase enzyme (which naturally found in whey) in detoxification of phenolic compounds which are naturally known as a constituent of ration fiber lignin (Kroon et al., 1999). The detoxification of phenolic compounds by natural peroxidase source cause an increase of digestibility of all nutrients (Monties, 1994). Also, the same author added that peroxidase is ligninolytic enzyme. Since most phenolic compounds are known to be enzyme inhibitor, the detoxification of it by any way cause increase in digestibility of all nutrients. Whey proteins are of special importance. They are mainly represented by $\beta$-lactoglobulin, $\alpha$-lactalbumin, immunoglobulins, bovine serum albumin, lactoferrin and lacto-peroxidase (Brodziak et al., 2012).

Table 3: Digestibility coefficients (\%) and feeding values (\%) of the experimental diets.

\begin{tabular}{|c|c|c|c|c|c|c|}
\hline \multirow[b]{2}{*}{ Item } & \multicolumn{5}{|c|}{ Experimental rations } & \multirow[b]{2}{*}{ SE } \\
\hline & $\begin{array}{c}\text { R1 } \\
\text { Control }\end{array}$ & $\begin{array}{c}\text { R2 } \\
\text { 0\% } \\
\text { Whey } \\
\end{array}$ & $\begin{array}{c}\text { R3 } \\
1 \% \\
\text { Whey } \\
\end{array}$ & $\begin{array}{c}\text { R4 } \\
2 \% \\
\text { Whey } \\
\end{array}$ & $\begin{array}{c}\text { R5 } \\
3 \% \\
\text { Whey } \\
\end{array}$ & \\
\hline \multicolumn{7}{|c|}{ Digestion coefficients (\%): } \\
\hline DM & $73.97^{\mathrm{bc}}$ & $71.4^{\mathrm{a} C}$ & $70.23^{\mathrm{d}}$ & $75.57^{\mathrm{ba}}$ & $77.64^{\mathrm{a}}$ & \pm 0.94 \\
\hline OM & $74.58^{\mathrm{bc}}$ & $72.12^{\underline{d} C}$ & $70.93^{\underline{a}}$ & $76.06^{\mathrm{ba}}$ & $78.1^{\mathrm{a}}$ & \pm 0.92 \\
\hline $\mathrm{CP}$ & $81.15^{a}$ & $78.27^{b}$ & $78.01^{b}$ & $80.89^{a}$ & $82.24^{a}$ & \pm 0.72 \\
\hline $\mathrm{CF}$ & $27.08^{\mathrm{bac}}$ & $22.41^{b c}$ & $18.01^{\mathrm{C}}$ & $31.94^{\text {ba }}$ & $36.1^{a}$ & \pm 2.59 \\
\hline EE & $91.06^{b}$ & $89.55^{\mathrm{C}}$ & $90.21^{\mathrm{cb}}$ & $94.09^{a}$ & $93.56^{\mathrm{a}}$ & \pm 0.31 \\
\hline NFE & $81.9^{a}$ & $78.64^{b}$ & $78.93^{b}$ & $82.26^{\mathrm{a}}$ & $83.53^{\mathrm{a}}$ & \pm 0.69 \\
\hline \multicolumn{7}{|c|}{ Fiber fractions (\%): } \\
\hline NDF & $57.45^{\mathrm{ba}}$ & $52.95^{b c}$ & $49.37^{\mathrm{c}}$ & $61.02^{\mathrm{a}}$ & $61.43^{a}$ & \pm 1.56 \\
\hline ADF & $56.03^{b c}$ & $51.13^{\frac{d}{C}}$ & $50.23^{\underline{d}}$ & $59.00^{\mathbf{b a}}$ & $62.99^{a}$ & \pm 1.59 \\
\hline H. Cellu. & $59.29^{b a}$ & $55.37^{b}$ & $48.22^{b c}$ & $63.73^{a}$ & $59.32^{b_{a}}$ & \pm 1.52 \\
\hline Cellulose & $56.98^{\mathrm{bc}}$ & $52.93^{\mathrm{d} C}$ & $51.18 \underline{q}$ & $58.21^{\mathrm{ba}}$ & $62.57^{a}$ & \pm 1.56 \\
\hline Lignin & $53.96^{b}$ & $47.12^{\mathrm{C}}$ & $48.10^{C}$ & $60.75^{a}$ & $63.91^{\mathrm{a}}$ & \pm 1.66 \\
\hline \multicolumn{7}{|c|}{ Nutritive values (\%): } \\
\hline TDN & $73.64^{\mathrm{ba}}$ & $70.2^{\mathrm{bc}}$ & $69.37^{c}$ & $73.78^{b a}$ & $75.3^{a}$ & \pm 0.97 \\
\hline $\mathrm{DCP}$ & $15.50^{\mathrm{a}}$ & $14.37^{\mathrm{ca}}$ & $14.29^{\mathrm{a}}$ & $14.78^{\mathrm{cb}}$ & $15.00^{b}$ & \pm 0.13 \\
\hline $\mathrm{DE}$ & $11.44^{\mathrm{b}}$ & $11.08^{b}$ & $11.01^{b}$ & $11.93^{a}$ & $12.37^{a}$ & \pm 0.14 \\
\hline $\mathrm{ME}$ & $10.87^{b}$ & $10.53^{b}$ & $10.46^{b}$ & $11.34^{\mathrm{a}}$ & $11.76^{a}$ & \pm 0.14 \\
\hline
\end{tabular}

Szczurek et al., (2013) reported that although birds were fed diets containing whey protein concentration yet they had numerically the lowest $\mathrm{pH}$ in the caeca and in the small intestine, and the greatest relative intestinal 
weight compared to the control group. They also indicated that the improvement in growth rate of WPC-fed birds occurred was primarily due to better nutrient digestibility and/ or the capacity of the intestines to absorb nutrients.

With regard fiber fractions additive whey to diet 2 with 2 or $3 \%$ significantly $(P<0.01)$ increased with rabbits fed ration 4 and 5 . The present results in Table 3 indicated that the nutritive value as TDN significantly $(P<0.01)$ increased with rabbits fed ration 5 (3\%whey) compared with other rations, while rabbits fed control and ration 4 ( $2 \%$ whey) significantly $(P<0.01)$ increased with rabbits fed rations $2(0 \%$ whey) and 3 (1\%whey). There were significant $(\mathrm{P}<0.01)$ increase in TDN when whey was added at the rate of 2 and $3 \%$ in rations 3 and 4 respectively. Moreover, rabbits fed the control un supplemented recorded the highest $(P<0.01)$ values of $D C P$, followed by those fed ration 5 (3\%whey). The data showed that DE and ME significantly $(P<0.01)$ increased with rabbits fed ration 4 and 5 ( 2 and $3 \%$ whey).

\section{Productive performance:}

\section{1- Changes of live body weight:}

Effect of feeding experimental diets on LBW of rabbits during the experimental periods (35 to 107 days) are presented in Table 4. At the beginning of the experiment, the initial body weight of the experimental rabbits were $671.67,680.00,678.33,681.67$ and $683.33 \mathrm{~g}$ for the control, ration 2, 3, 4 and 5,respectively,indicating unbiased distribution of individuals among the treatment groups. Also, 24 days later, there was no significant differences in body weight, but rabbits fed ration 2 (1\%whey) had numerically the highest body weight compared to other groups. After 48 days, groups fed control, rations 3 and 4 ( 1 and $2 \%$ whey) had significantly $(P<0.05)$ higher body weight than that of ration 2 and 5 . The final weight was significantly $(P<$ 0.01 ) higher in all groups compared to the control ration R1 (0\% whey). The increases might be attributed to the higher digestibility of most nutrients, fiber fractions digestibility and nutritive values. The increase in live body weight (LBW) and live body weight gain (LBWG) of rabbits fed diets supplemented with whey (as source of peroxidase enzyme) at 1,2 and $3 \%$ to diet are in agreement with the findings of Eiben et al. (2002), Gidenne et al., (2002) and Zheng et al. (2012). Eiben et al., (2002) found that feeding rabbit a diet supplemented with cellulose enzyme significantly improved weight gain. Also, Gutierrez et al., (2002) showed that addition of enzymes has improved BWG of young rabbits (by $3.1 \%$ ) from 25 to 39 days of age. Gidenne et al., (2002) reported that the improvement in live BW and BWG of the rabbits fed enzymes may be due to the enhancing effect of enzymes in microflora growth in gut and cecum as well as increase in volatile fatty acids production and organic matter digestibility. Antioxidant enzymes were an important indicator of animals' physical health and reaction in response to external stimuli (Johnson, 2002). 
Table 4: Live body weight of growing NZW rabbits as affected by feeding the experimental diets at different periods.

\begin{tabular}{|c|c|c|c|c|c|c|}
\hline \multirow[b]{2}{*}{ Item } & \multirow[b]{2}{*}{$\begin{array}{c}\text { R1 } \\
\text { Control }\end{array}$} & \multicolumn{4}{|c|}{ Experimental rations } & \multirow[b]{2}{*}{ SE } \\
\hline & & $\begin{array}{c}\text { R2 } \\
0 \% \\
\text { Whey }\end{array}$ & $\begin{array}{c}\text { R3 } \\
1 \% \\
\text { Whey }\end{array}$ & $\begin{array}{c}\text { R4 } \\
2 \% \\
\text { Whey }\end{array}$ & $\begin{array}{c}\text { R5 } \\
3 \% \\
\text { Whey }\end{array}$ & \\
\hline \multicolumn{6}{|c|}{ Live body weight (LBW) (g) at } & \\
\hline 35 days & 671.7 & 680.0 & 678.3 & 681.7 & 683.3 & \pm 52.72 \\
\hline 59 days & 1416.7 & 1479.67 & 1541.7 & 1521.7 & 1475.0 & \pm 49.59 \\
\hline 83 days & $2015^{a}$ & $1859^{b}$ & $2060^{a}$ & $2028.3^{a}$ & $1950.0^{b a}$ & \pm 41.55 \\
\hline 107 days & $2545.0^{a}$ & $2248.3^{b}$ & $2466.7^{a}$ & $2470.5^{a}$ & $2456.7^{a}$ & \pm 42.15 \\
\hline
\end{tabular}

\section{2-Changes in body weight gain:}

Means of average daily gain ( $g$ ) for the five experimental groups (control, rations 2, 3, 4 and 5) are presented in Tables 5.

During the first period of the experiment $\left(5^{\text {th }}\right.$ week) body weight gain and average daily gain $(\mathrm{g})$ indicated no significant difference $(P \leq 0.05)$ among the tested groups. However, 24 and 48 days later rabbits fed control diet had the highest body weight gain compared to the other experimental groups. But feeding rations supplemented with whey (R3, R4 and R5) significantly (Ps $0.05)$ increased gain compared ration 1. At the end of experimental periods the results indicated significant $(P \leq 0.05)$ increase for control and other rations contained whey compared with ration 2 ( $0 \%$ whey).

Table 5: Live body weight gain of growing NZW rabbits as affected by feeding the experimental diets.

\begin{tabular}{|c|c|c|c|c|c|c|}
\hline \multirow[b]{2}{*}{ Item } & \multirow[b]{2}{*}{$\begin{array}{c}\text { R1 } \\
\text { Control }\end{array}$} & \multicolumn{4}{|c|}{ Experimental rations } & \multirow[b]{2}{*}{ S.E } \\
\hline & & $\begin{array}{c}\text { R2 } \\
\text { 0\% } \\
\text { Whey }\end{array}$ & $\begin{array}{c}\text { R3 } \\
1 \% \\
\text { Whey }\end{array}$ & $\begin{array}{c}\text { R4 } \\
2 \% \\
\text { Whey }\end{array}$ & $\begin{array}{c}\text { R5 } \\
3 \% \\
\text { Whey }\end{array}$ & \\
\hline \multicolumn{7}{|c|}{ Average weight gain $(\mathrm{g})$ at } \\
\hline 35- $59(d)$ & 745.0 & 799.7 & 863.3 & 840.0 & 791.67 & \pm 52.57 \\
\hline $59-83(d)$ & $598.3^{a}$ & $379.3^{\mathrm{C}}$ & $518.3^{b_{a}}$ & $506.7^{\mathrm{b} a}$ & $475.0^{b}$ & \pm 31.35 \\
\hline $83-107(d)$ & $530.0^{a}$ & $389.3^{\mathrm{C}}$ & $406.7^{\mathrm{C}}$ & $442.2^{\mathrm{b} \mathrm{a}^{\mathrm{C}}}$ & $506.7^{0} a$ & \pm 34.84 \\
\hline 35- $107(d)$ & $1873.3^{a}$ & $1568.3^{b}$ & $1788.3^{a}$ & $1788.8^{a}$ & $1773.3^{a}$ & \pm 58.94 \\
\hline \multicolumn{6}{|c|}{ Average daily gain (g) } & \\
\hline 35- $59(d)$ & 31.04 & 33.32 & 35.97 & 35 & 32.99 & \pm 2.19 \\
\hline $59-83(d)$ & $24.93^{a}$ & $15.81^{\mathrm{C}}$ & $21.6^{b_{a}}$ & $21.11^{b a}$ & $19.79^{b}$ & \pm 1.31 \\
\hline 83- 107 (d) & $22.09^{a}$ & $16.22^{\mathrm{C}}$ & $16.95^{\mathrm{bc}}$ & $18.43^{\mathrm{b} \mathrm{a}^{\mathrm{c}}}$ & $21.11^{\mathrm{b} a}$ & \pm 1.45 \\
\hline $35-107(d)$ & $26.02^{\mathrm{a}}$ & $21.78^{b}$ & $24.84^{a}$ & $24.85^{a}$ & $24.63^{a}$ & \pm 0.82 \\
\hline
\end{tabular}

Eiben et al., (2002) found that feeding rabbits a diet supplemented with cellulose enzyme significantly improved weight gain. Also, Gutierrez et al., (2002) showed that addition of enzymes has improved BWG of young rabbits by $3.1 \%$ from 25 to 39 days of age. Abd El-Latif et al., (2008) reported that enzymes supplementation improved body weight gain for rabbits fed diets 
containing $10 \%$ CF during the experimental period. Kanyinji and Sichangwa (2014) reported that replacing soybean meal with 15 and $20 \%$ fermentation cottonseed meal and 15\% cottonseed meal in broiler finishing diets had no significant effect on the parameters assessed. However, broilers fed diets with $20 \%$ CSM had lower $(p<0.05)$ daily weight gain or total weight gained compared to birds in other treatments.

\section{Economical efficiency:}

Data of economic evaluation of replacing CSM for SBM (ration 2) and addition of whey (rations 3, 4 and 5) is given in Table 6.

Results revealed that groups fed ration 3,5 and 4 (1, 3 and $2 \%$ whey) achieved the best economic efficiency (163.41, 159.72 and $150.05 \%)$ and relative economic efficiency (119.27, 116.58 and $109.52 \%)$. The least value was recorded for the control group. This improvement in feed efficiency was a reflection of improved body weight gain with less feed intake and the cheap price of whey when added as a natural source of peroxidase enzyme to rations 3,5 and 4 .

Table 6: Economical efficiency of growing NZW rabbits as affected by feeding the experimental diets at the end of lactation period.

\begin{tabular}{|c|c|c|c|c|c|}
\hline \multirow[b]{2}{*}{ Item } & \multicolumn{5}{|c|}{ Experimental group } \\
\hline & $\begin{array}{c}\mathrm{R} 1 \\
\text { Control }\end{array}$ & $\begin{array}{c}\text { R2 } \\
\text { 0\% } \\
\text { Whey }\end{array}$ & $\begin{array}{c}\text { R3 } \\
1 \% \\
\text { Whey }\end{array}$ & $\begin{array}{c}\text { R4 } \\
2 \% \\
\text { Whey }\end{array}$ & $\begin{array}{c}\text { R5 } \\
3 \% \\
\text { Whey }\end{array}$ \\
\hline Average feed intake (kg/buck) & 7.50 & 6.88 & 7.15 & 7.32 & 7.083 \\
\hline Price/ kg feed (LE)* & 2.91 & 2.57 & 2.58 & 2.59 & 2.60 \\
\hline Average weight gain (kg/doe) & 2.587 & 2.153 & 2.430 & 2.403 & 2.392 \\
\hline Price /kg live body $(\mathrm{LE})^{* *}$ & 20 & 20 & 20 & 20 & 20 \\
\hline Total feed cost (LE) & 21.83 & 17.68 & 18.45 & 19.22 & 18.42 \\
\hline Price of weight gain (LE) & 51.74 & 43.06 & 48.6 & 48.06 & 47.84 \\
\hline Feed conversion ratio & 2.90 & 3.19 & 2.94 & 3.04 & 2.96 \\
\hline Net revenue (LE) & 29.91 & 25.38 & 30.15 & 28.84 & 29.42 \\
\hline Economic efficiency (\%) & 137.01 & 143.55 & 163.41 & 150.05 & 159.72 \\
\hline Relative economic efficiency (\%) & 100 & 104.44 & 119.27 & 109.52 & 116.58 \\
\hline
\end{tabular}

\section{CONCLUSION}

In conclusion, according of the results of the present study, presence of anti nutritional factors such as phenolic compounds in feedstuffs may limit their use in formulating rations for rabbits as well as having a negative impact on utilization of those feedstuffs. The positive results of this current study may encourage the use of whey as cheap natural source of peroxidase enzyme at 1,2 or $3 \%$ levels to decrease the deleterious effects of phenolic compounds in feed material to a safe level and to upgrade their nutritive values. 


\section{REFERENCES}

Abd El-Hadi, Sherein, H. (2011). Effect of some natural sources of the peroxidase on degradation of phenolic compounds in buffalo calves rations. Ph. D. Cairo Unv.

Abd El-Latif, S. A.; Mohammed, K. A.; Kawsar, A. Ghaly and Maha A. Abd ElLatif. (2008). Effect of using commercial enzymes on performance and some metabolic functions of rabbits fed grade levels of crude fiber. Egypt. Poul. Sci., 28 (IV): 1003- 1022.

AOAC (1990). Official Methods of Analysis. 15 ${ }^{\text {th }}$ edition. Association of Agriculture Chemists. Washington DC., USA.

Azevedo, A. M.; Martins, V. C.; Prazeres, D. M.; Vojinovic, V.; Cabral, J. M. S. and Fonseca, L. P. (2003). Horseradish peroxidase: a valuable tool in biotechnology. Bio. annual Rev., 9: 199- 247.

Azhdari, R. E.; Doust, R. S.; Lak, A. (2012). Determination of cottonseed meal degradability with nylon bag Technique. Annals of Biol. Rese., 3 (3): 1398-1401.

Brodziak, A.; Barłowska, J.; Król, J. and Litwińczuk, Z. (2012). Effect of breed and feeding system on content of selected whey proteins in cow's milk in spring-summer and autumn-winter seasons. Annals. Anim. Sci., 12: 261- 269.

Cheeke, P. R. (1987). Rabbit feeding and nutrition. Academic press, Orland, FL., USA.

Dadgar, S.; Bin Saadm C. R.; Alimon, A.R.; Kamarudin, M.S. and Nafisi, B. M. (2010). Comparison of soybean meal and cottonseed meal varietypak (CSMP) on growth and feed using in rainbow trout (Oncorhynchus mykiss). Iranian J. of Fisheries Sci., 9(1): 49- 60.

Duncan, D.B. (1955). Multiple range and multiple $F$ test. Biometrics, 11:1.

Eiben, C. S.; Mezes, M.; Szijarton, N.; Kustos, K.; Godor- Surmann, K. and Erdelyi, M. (2002). Dose-dependent effect of cellulase supplementation on performance of early weaned rabbit. Dep. of Agri. Chem. Techn., Budapest Univ. of Technology and Economics, H-1521 Budapest, P. O. Box 91, Hungary.

Erturk, M. M.; Ozen, N. and Celik, K. (2004). Effects of replacement of soybean meal by cottonseed meal on laying performance and haemoglobin levels in practical diets for breeder Japanese quail, (Coturnixcoturnix japonica). Asian-Aust. J. Anim. Sci., 17(7): 980- 983.

Gidenne, T.; Jehl, N.; Segura, M. and Michalet- Doreau, B. (2002). Microbial activity in the caecum of the rabbit around weaning: impact of a dietary fiber deficiency and of intake level. Ani. Feed Sci. and Techn., 99:107118.

Goering, H. K. and Van Soest, P. J. (1970). Forage Fiber Analysis ( apparatus, reagents, procedures and some applications). USDA, Agricultural Handbook No, 379. 
Gutierrez, T.; Espinosa, A.; Garcia, J.; Carabano, R. and De Blas, J. C. (2002). Effect of starch and protein sources, heat processing, and exogenous enzymes in starter diets for early weaned rabbits. Anim. Feed Sci., Technol., 98: 174- 186.

Johnson, P. (2002). Antioxidant enzyme expression in health and disease: effects of exercise and hypertension. Comp Bioch. Physiol. Part C., 133: 493- 505.

Kanyinji, F. and Sichangwa, M. (2014). Performance of broilers fed finishing diets with fermented cotton seed meal as partial replacement for soybean meal. J. Anim. Sci., 4(7): 931- 938.

Kumar, R. (2003). Anti-nutritive factors, the potential risks of toxicity and methods to alleviate them. http://www.fao.org.

Kroon, P. A.; Garcia-Conesa, M. T.; Fillingham, I. J.; Hazlewood, G. P. and Williamson, G. (1999). Release of ferulic acid dehydrodimers from plant cell walls by feruloylesterases. J. Sci. Food Agric., 79(3): 428434.

Monties, B. (1994). Chemical assessment of lignin biodegradation some qualitative and quantitative aspects. Federation of Europ. Microbi. Soci., 13: 277- 283.

Nasrabadi, T. H. and Asadpour, R. (2008). Effect of heat treatment on buffalo (Bubalus bubalis) lactoperoxidase activity in raw milk. J. of Biol. Sci., 8 (8): 1310- 1315.

National Research Council (NRC), (1994). Nutrient Requirements of Poultry, $9^{\text {th }}$ Revised Edition, National Academy Press, Washington, DC.

Ojewola, G. S.; Ukachukwu, S. N. and Okulonye, E. I. (2006). Cottonseed meal as substitute for soyabean meal in broiler ration. Inter. J. of Poult. Sci., 5 (4): 360- 364.

SAS Institute (2001). SAS User's Guide Statistics. SAS Inst. Inc. Cary. NC. USA.

Shakeel-ur-Rehman and Farkye, N. Y. (2002). Lactoperoxidase. In: encyclopedia of dairy science, $1^{\text {st }}$ Edn., Roginski, R.;Fequay, J. W. and Fox, P. F. (Eds.).Academic Press, Amsterdam: 939- 941.

Snedecor, G. W. and Cochran, W. G. (1982). Statistical Methods ( $7^{\text {th }}$ edition). Biometrics 38 (1): 292.

Szczurek, W.; Szymczyk, B.; Arczewska-Włosek, A.; Józefik, D. and Alloui, M. (2013). The effects of dietary whey protein concentrate level on performance, selected intestinal tract and blood parameters, and thiobarbituric acid reactive substances in the liver and breast meat of broiler chickens. J. of Ani. and Feed Sci,, 22: 342- 353.

The European whey product association. (EWPA) (2006). Whey in animal nutrition A valuable ingredient. Brussels, Belgium. http// www. Euro milk.org/ewpa.

Zheng, Q.; Wen, X.; Han, C.; Li, H. and Xie, X. (2012). Effect of replacing soybean meal with cottonseed meal on growth, hematology, antioxidant enzymes activity and expression for juvenile grass carp, (Ctenopharyngodon Idellus). Fish Physiol. Biochem., 38(4): 10591069. 


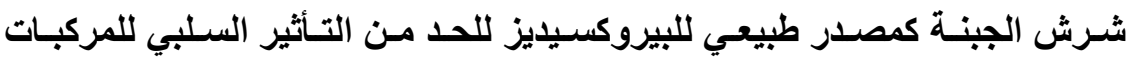

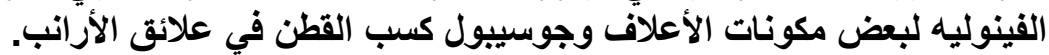

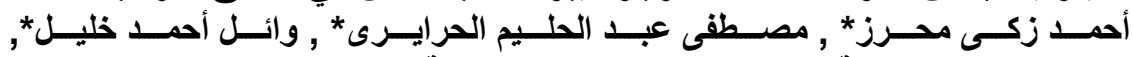

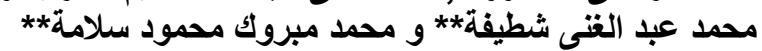

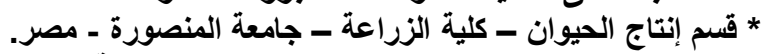

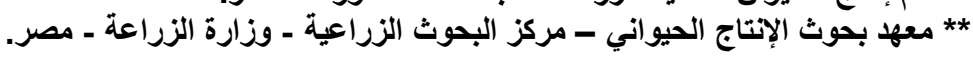

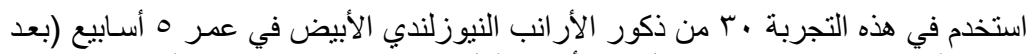

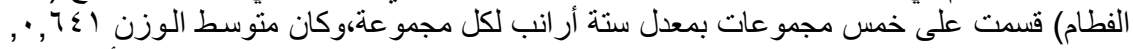

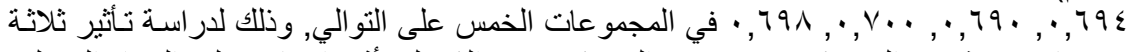

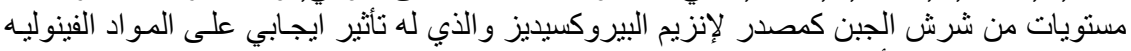

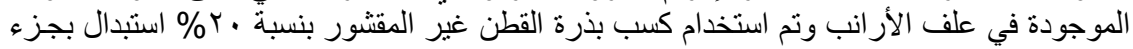

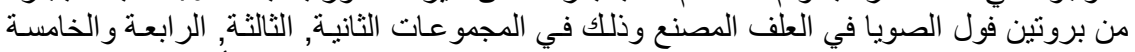

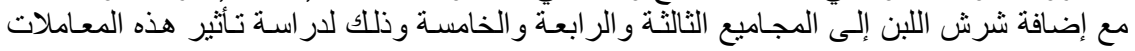

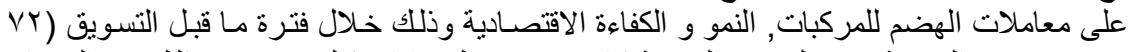

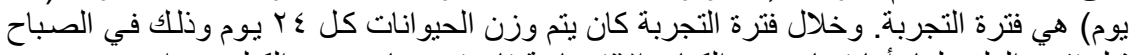

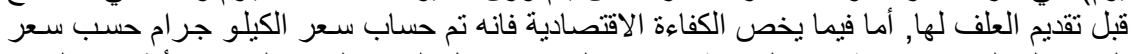

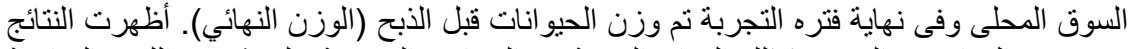

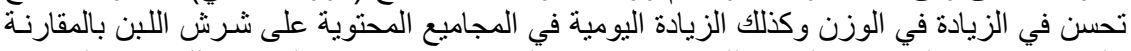

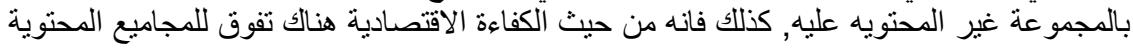

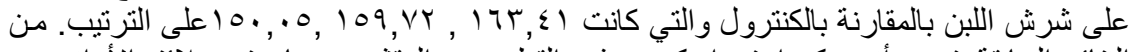

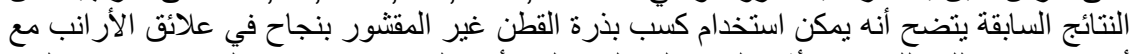

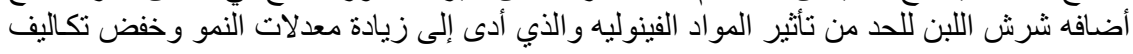
الإنتاج. 